\title{
ArcheoSciences
}

Revue d'archéométrie

29 | 2005

Varia

\section{Investigations on ancient beads from the Sultanate of Oman (Ra's al-Hadd - Southern Oman)}

Liliana Panei, Gilberto Rinaldi and Maurizio Tosi

\section{OpenEdition}

1 Journals

\section{Electronic version}

URL: http://journals.openedition.org/archeosciences/643

DOI: 10.4000/archeosciences.643

ISBN: 978-2-7535-1594-9

ISSN: $2104-3728$

Publisher

Presses universitaires de Rennes

\section{Printed version}

Date of publication: 31 December 2005

Number of pages: 151-155

ISSN: 1960-1360

\section{Electronic reference}

Liliana Panei, Gilberto Rinaldi and Maurizio Tosi, "Investigations on ancient beads from the Sultanate of Oman (Ra's al-Hadd - Southern Oman)", ArcheoSciences [Online], 29 | 2005, Online since 31

December 2007, connection on 11 February 2021. URL: http://journals.openedition.org/ archeosciences/643 ; DOI: https://doi.org/10.4000/archeosciences.643 


\title{
Investigations on ancient beads from the Sultanate of Oman (Ra's al-Hadd - Southern Oman)
}

\author{
Liliana PANEI*, Gilberto RINALDI** et Maurizio TOSI***
}

\begin{abstract}
A study has been carricd out on the mineralogical composition of stone beads found in the course of archacological excavations carricd out at the site of Ra's al-Hadd in Southern Oman.

The data provide information about the raw material and technology used for beads production.

Several beads and micro-beads made of white paste of different shapes and sizes have been analysed

They range, in sizc, from two to four millimetres in diameter, two to fifteen millimetres in height, and the diameter of the hole is approximately one millimetre.

The shape is tubular for the biggest bead, cylindrical for slender beads and ring-shaped for micro-beads.

The beads werc analysed using X-ray diffraction (XRD); the method was optimised to minimise the amount of the sample necessary for analysis (15 milligrams were necessary using special sample holders while in traditional holders 300 milligrams are needed).

XRD analysis revealed that the beads arc made of "synthetic enstatite", a magnesium silicate belonging to pyroxene group (orthopyroxene $\mathrm{Mg}_{2} \mathrm{Si}_{2} \mathrm{O}_{6}$ ).

The relative intensity of the main peaks confirms that the material is "synthetic enstatite".

Natural enstatitc is a hard mincral (its hardness is five or six on the Mohs scalc), therefore we propose that a softer magnesium-bcaring mineral was used: steatitc $\left(\mathrm{Mg}_{3} \mathrm{Si}_{4} \mathrm{O}_{6 \mathrm{f}}(\mathrm{OH})_{2}\right.$ commonly known as massive talc - hardness onc on the Mohs scalc).

The beads might have been worked from soft steatite bulk material and then hardened by transformation of the steatite to synthetic enstatite during firing at about $1000^{\circ} \mathrm{C}$ so that the formerly soft beads became hard and durable.

Some preliminary heating experiments on talc bulk fircd at about $1000^{\circ} \mathrm{C}$ was carricd out to compare powder diffractograms of the beads and the fired massive talc; a good overall resemblance of the two patterns is evident.

The raw material of the examined beads might have came from the ultramafic rocks of Oman and it is very likely that these beads were produced from locally available raw matcrials.
\end{abstract}

Résumé : Nous avons ćtudić la composition minéralogique des petites perles trouvées lors des fouilles archéologiques effectuées sur le site de Ra's al-Hadd situć au sud de l'Oman. Nous avons analysé beaucoup de petites perles et micro-pcrles fabriquées avec un matériel blanc ct de différentes formes et dimensions. Les résultats de l'analyse ont livré des informations sur le matériel ct la technologic utilisés pour la production des petites perles.

Les dimensions sont de deux à quatre millimètres de diamètre et de deux à quinze millimètres de haut, le diamètre du trou perforé est approximativement de un millimètre. La forme cst tubulaire pour la perle la plus grande et cylindrique pour les plus petites peries, de forme circulaire pour les micro-perles. Les petites perles ont été analysées par diffraction de rayons $X$. Nous avons optimisé la méthode pour minimiser la quantité de matéricl utilisé pour l'analyse $(15 \mathrm{mg}$ de poudre sont nécessaircs avec un porte ćchantillon spécial contre $500 \mathrm{mg} \mathrm{de} \mathrm{poudre} \mathrm{nécessaires} \mathrm{avec} \mathrm{un} \mathrm{portc} \mathrm{échantillon} \mathrm{traditionnel).} \mathrm{L'analyse} \mathrm{par} \mathrm{diffraction} \mathrm{de} \mathrm{rayons} \mathrm{X}$ indique que les petites peries sont en enstatitc synthétique, un silicate de magnésium appartenant au groupe des pyroxènes (ortopyroxéne $\mathrm{Mg}_{2} \mathrm{Si}_{2} \mathrm{O}_{6}$ ). L'intensité relative des pics principaux confirme que le matériel utilisé est l'enstatitc synthétique. L'enstatite naturelle est un minéral très dur (il a une dureté de cinq à six sur l'échelle Mohs) et c'est pourquoi nous proposons que la stéatite $\left(\mathrm{Mg}_{2} \mathrm{Si}_{4} \mathrm{O}_{10}(\mathrm{OH})_{2}\right.$ normalement connue comme talc massif de dureté un sur l'échelle de Mohs) est le matériel utilisé pour la réalisation des petites perles.

Les petites perles pourraient avoir été réalisées avec de la stéatite et être ensuite transformées en cnstatite synthétique par cuisson au four à une température d'environ 1000 degrés centigrades. Cette méthode permettrait la production de petites perles très dures, réalisćes à partir d'un matériel tendre.

Nous avons fait des expériences avec du talc italien chauffé à 1000 degrés centigrades pour comparer les diagrammes de diffraction des petites perles avec les diagrammes de diffraction du talc chauffé.

Key-words: Bcads, Oman, stcatite, enstatite, pyro-technology, XRD.

Mots-clés : Perles, Oman, stéatite, enstatite, pyro-technologie, DRX.

\footnotetext{
* Laboratorio di Sperimentazione Mineraria e Petrografica, Ministero Attività Produttive, Largo S. Susanna 13,00187 ROME, Italy, e-mail: liliana. panei@attivilaproduttive.govit

** Dipartimento di Ingegneria Chimica, dei Materiali e delle Materie Prime, University of Rome "La Sapienza", Italy, e-mail: gilberto.rinaldi@ingchim. ing.uniromal.it

*** Dipartimento di Archeologia, Cattedra di Palemologia, University of Bologna, Italy, e-mail: tosimau@alma.unibo.it
} 


\section{Introduction}

A study has been carried out on the mineralogical composition of unglazed white stone beads found in the course of archaeological excavations carried out at the site of Ras al Hadd in Southern Oman. These excavations come under the Joint Hadd Project, an international group working under the aegis of the Ministry of National Heritage and Culture, Oman.

The remains of a costal community have been uncovered in the side located at the extreme eastern tip of the country, on a sandy spit between a lagoon and the Indian Ocean. The lagoon forms a natural port (Mosseri-Marlio, 1998). A thousand beads were found in 2002, in the early third millennium B.C. layers, in the area known as HD-6, which is rich in deposits, containing a large quantity of flint, worked stone and remains of bead manufacturing activity (Cattani \& Tosi, 1997; Cattani et al., 2001-2002). These beads were fashioned from diverse materials. We selected some of the white beads for material analysis.

The data provide information about the raw material and technology used for the production of the beads.

A comparison has also been performed with the data concerning samples analysed in previous archaeometric studies by some authors relative to similar white beads found in caves used as burial place in Samad Al Shan in Oman and Peqi' in in Israel (Rosch et al., 1997; Bar Yosef Mayer et al., 2004).

\section{Materials and methods}

\subsection{Description of the shape and size of the beads}

Several unglazed beads and micro-beads made of white paste, of different shapes and sizes have been analysed. The beads range, in size, from two to four millimetres in diameter and two to fifteen millimetres in height; the diameter of the hole is approximately one millimetre. The shape is tubular (truncated cone-shaped) for the biggest

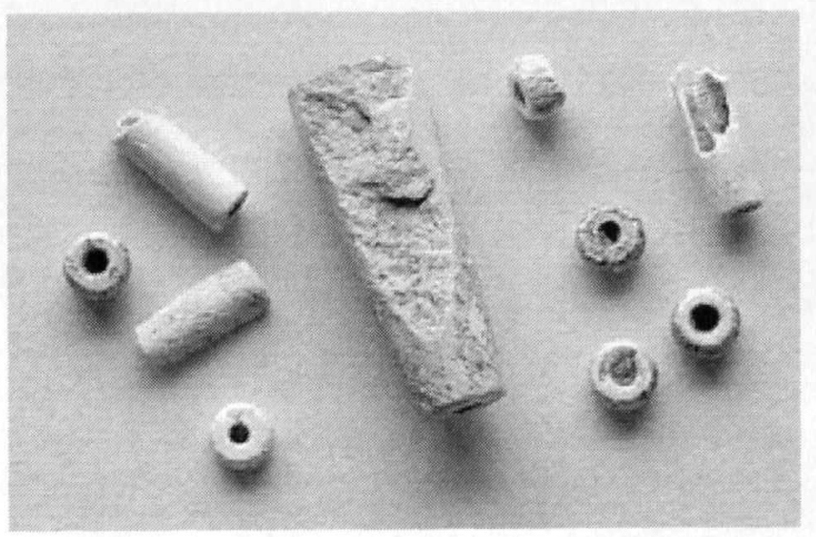

Figure 1: One truncated cone-shaped stone bead, site HD 6 - square R113 - US 703 - 2002; size: about $15 \mathrm{~mm}$ in height, from about $4 \mathrm{~mm}$ up to $5.5 \mathrm{~mm}$ in diameter, hole $1 \mathrm{~mm}$. Three slender cylindrical stone micro-beads, site HD 6 - square Q113 - US 789 - 2002; size: about 6 $\mathrm{mm}$ in height, about $2 \mathrm{~mm}$ in diameter, hole $1 \mathrm{~mm}$. Six ring-shaped stone micro-beads, site HD 6 - square Q114 - US 789 - 2002; size: about $2 \mathrm{~mm}$ in height, about $2 \mathrm{~mm}$ in diameter, hole about $1 \mathrm{~mm}$.

Figure 1 : Une perle tubulaire conique, trois petites perles cylindriques et six micro-perles circulaires sur le site HD6. bead, cylindrical for the slender beads and ring-shaped for the micro-beads (fig. 1).

\subsection{Analyses of the material}

The beads were analysed using X-ray diffraction (XRD). X-ray powder diffraction serves for qualitative analyses of crystalline phases and gives information about the crystal structure and the state of crystallinity of the sample; it can contribute to the unequivocal identification of materials used for the fabrication of ancient objects. Usually, the X-ray method is destructive (since powder sample is analysed) but we optimised the method to minimise the amount of sample necessary for analysis. We made a special sample holder which allows to carry out the analysis of small amounts of sample. Only 15 milligrams of pulverised bead were necessary using the special sample holder while in traditional holders up to 500 milligrams were needed; so a small amount of bead was sacrificed for analysis. The sample holder was made by carving a rectangular glass of the same shape and dimension as an ordinary sample-holder; we carved a wide but shallow well where the primary beam falls. We carefully filled the cavity with powder sample to obtain a flat surface. The good results obtained on some standard samples show that the method is valid for homogeneous samples even if the irradiated surface is rather small. The diffractrograms of the three types of the beads (tubular, cylindrical and ring-shaped) were superimposable. XRay diffraction pattern of the tubular bead is shown in figure 2 with the operating conditions. XRD analysis revealed that the beads of the three shapes are made of enstatite, a magnesium silicate belonging to pyroxene group (orthopyroxene $\mathrm{Mg}_{2} \mathrm{Si}_{2} \mathrm{O}_{6}$ ); in fact all reflections (peaks) of enstatite are present in the XRD patterns. Other crystalline phases do not appear. The relative intensity of the main peaks shows that the material is synthetic rather than natural enstatite.

The strongest lines and the relative intensities for enstatite and synthetic enstatite from Handbook "Powder

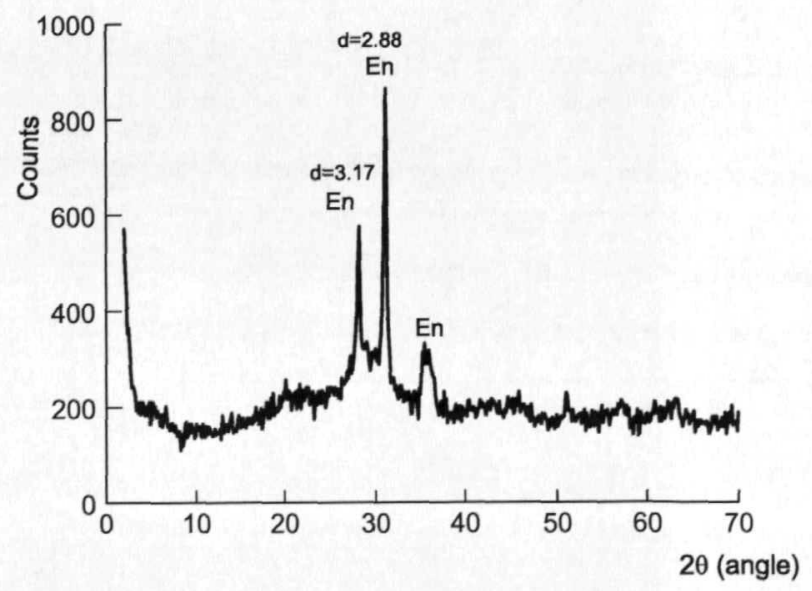

Figure 2: Diffractogram of the tubular bead - Philips Diffractometer PW 1830 -Operating conditions: Generator tension $40 \mathrm{KV}$ - Generator current $30 \mathrm{~mA}$ - Tube anode $\mathrm{Cu}$ - Filtro $\mathrm{Ni}$ - Divergence slit 1/2Receiving slit 0.2 - Start, end angles 2 - 70 degree - Step size 0.02 degree - Time per step $1 \mathrm{~s}$.

Figure 2 : Diffractogramme de la perle tubulaire. 
Diffraction File" - JCPDS (International Centre for Diffraction Data) are:

enstatite - (File 22-714) - 4.43(4)-3.31(6)-3.18(100)2.88(55)-2.54(25)-2.50(18)-2.48(18)

syntetic enstatite (File 19-768) - 4.41(20)-3.30(10)3.17(75)-2.87(100)-2.53(18)-2.49(8)-2.47(10).

Enstatite is a hard mineral that is difficult to carve (hardness five or six on the Mohs scale) but synthetic enstatite can be obtained from a soft and rather common magnesium-bearing mineral, steatite $\left(\mathrm{Mg}_{3} \mathrm{Si}_{4} \mathrm{O}_{10}(\mathrm{OH})_{2}\right.$ -massive talc- hardness one on the Mohs scale). Upon heating, steatite decomposes and recrystallizes to give (1) enstatite and a silica phase $\left(\mathrm{SiO}_{2}\right)$ :

$2 \mathrm{Mg}_{3} \mathrm{Si}_{4} \mathrm{O}_{10}(\mathrm{OH})_{2} \longrightarrow 3 \mathrm{Mg}_{2} \mathrm{Si}_{2} \mathrm{O}_{6}+2 \mathrm{SiO}_{2}$

\section{Discussion}

\subsection{Manufacturing process of steatite beads}

We propose that steatite was used in the manufacturing process of the beads. The beads might have been made from soft steatite material and then hardened by firing at about $1000^{\circ} \mathrm{C}$; the formerly soft beads thus became hard and durable. This hardening is due to the transformation of the steatite into synthetic enstatite which takes place at about $1000^{\circ} \mathrm{C}$.

Several technological mode of production might have been used:

- beads might have been directly carved out from bulk steatite;

- beads might have been produced by reshaped powder steatite (paste powdered steatite-water);

- beads might have been produced by pastes made of powdered steatite and a flux.

We carried out some preliminary heating experiments on bulk talc fired at $1000^{\circ} \mathrm{C}$ for 9 hours. The bulk talc became a hard and compact material when heated. We used a Italian talc from Val Germanasca (Piemonte). The strongest lines were: 9.35(100)-3.67(19)-3.12(100)$1.87(7)-1.56(3)$. We compared diffractograms of the

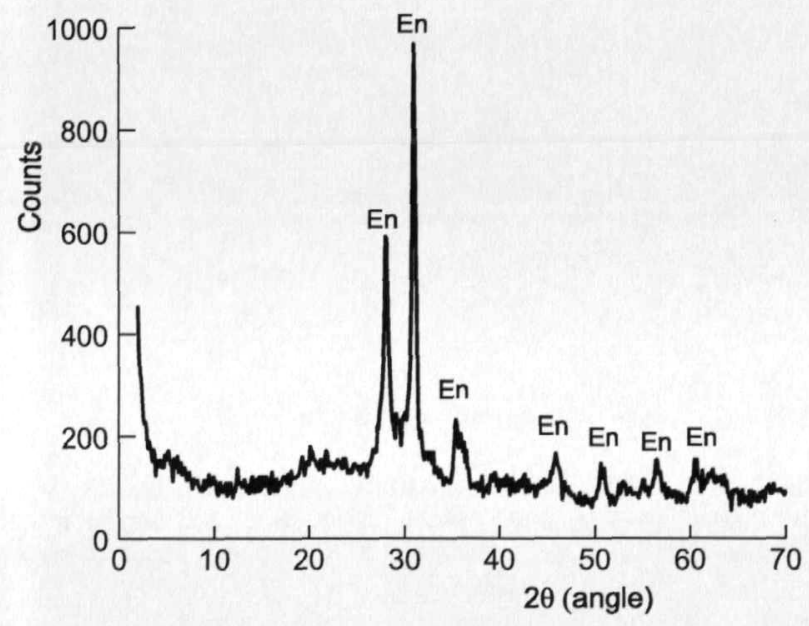

Figure 3: Diffractogram of the massive talc fired at $1000^{\circ} \mathrm{C}$. Figure 3 : Diffractogramme de talc cuit à $1000^{\circ} \mathrm{C}$. beads (fig. 2) and the fired massive talc (fig. 3). A very good overall resemblance of the patterns was evident. The figures show that the diffractrograms of the beads and the fired talc bulk are quite superimposable. Enstatite is identified as the only crystalline component. The high background below the main peaks of enstatite is due to amorphous silica, residual product of transformation from talc to enstatite.

As beads may also have been produced by reshaped talk powder, we also tried to fire a talc paste made of finely powdered talc mixed with water; the paste was reshaped into cylinders. The experiment failed completely: shaping the cylinder was very difficult and the slightest touch reduced the fired cylinder to powder. The diffractogram of the fired paste (fig. 4) showed that enstatite and cristobalite were the mineralogical phases. Cristobalite is a crystalline silica phase, residual product of transformation from talc to enstatite.

Since cristobalite did not appear when we fired massive talc at the same temperature, we deduce that the grinding of talc promotes the crystallization of cristobalite during firing.

As heating experiments showed that the paste formed by powdered talc and water would not fuse under these conditions, we also tried two pastes obtained by mixing powdered talc, water and a flux: montmorillonite clay or sodium-feldspar.

At our first attempt we added about $10 \%$ in weight of montmorillonite clay from Wyoming to powdered talc; the crude paste showed a good workability and when heated became a hard and compact material. The diffractogram of the heated paste showed enstatite, cristobalite and quartz (a crystalline silica phase contained as additional component in the clay).

In further attempts we fired at 1000 and $1100^{\circ} \mathrm{C}$ a paste made of powdered talc and a sodium feldspar ${ }^{1}(13 \%$ in weight); the crude paste was workable enough to shape small cylinders but the slightest touch reduced the fired

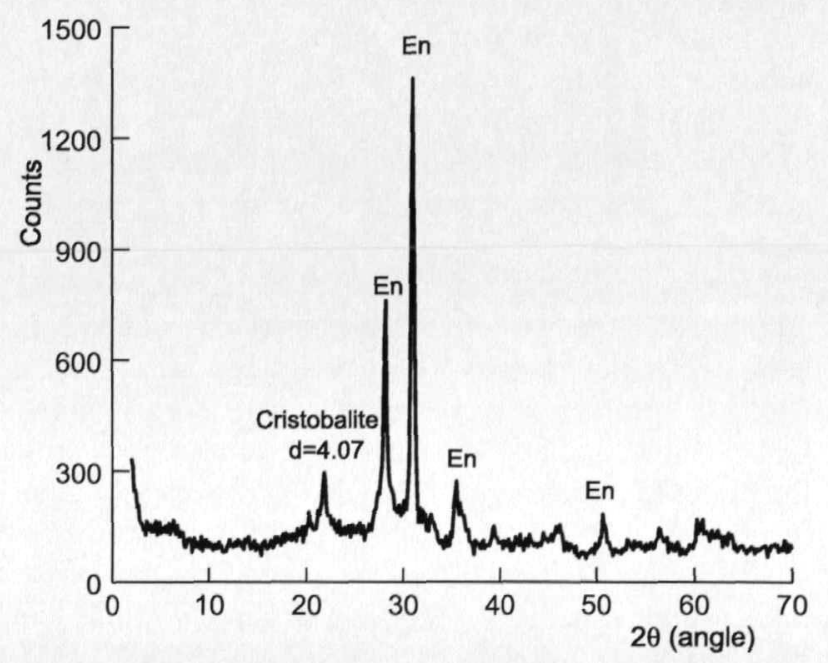

Figure 4: Diffractogram of the paste made of powdered talc-water, fired at $1000^{\circ} \mathrm{C}$

Figure 4: Diffractogramme d'une pâte faite d'un mélange talc-eau, cuit à $1000^{\circ} \mathrm{C}$.

\footnotetext{
${ }^{1}$ We used an italian feldspar from Catanzaro (Calabria). Mineralogical composition: $83 \%$ sodium feldspar, $12 \%$ chlorite, $4 \%$ quartz.
} 
cylinders to powder. The diffractograms showed that the mineralogical phases of the fired pastes were enstatite, cristobalite and untransformed feldspar.

Since this paste didn't fuse up to $1100^{\circ} \mathrm{C}$, we raised the temperature up to $1250^{\circ} \mathrm{C}$ and thus obtained a hard and compact material. The diffractogram of the heated paste showed protoenstatite (high temperature-syntetic enstatite $)^{2}$, cristobalite and a small amount of untransformed feldspar.

Based on the results of heating experiments on talc it seem reasonable to think that the beads were directly carved out of bulk steatite and then hardened by firing.

\subsection{Previous studies relative to enstatite beads}

Similar white beads, some of which glazed, were discovered in several areas in the East: Indus Valley (Harappa), Upper Egypt, Umm An-Nar Island and Samad Al Shan (Oman), northern Galilee, Pakistan, Jebel al Emalah (UAE). For many years this material was regarded as birds bone or shell or faience, only in 1984 the material was analysed by Ole Johnsen from the Mineralogical Museum of Copenhagen and identified as enstatite (Frifelt, 1991). In the last few years enstatite beads have been studied (Vidale, 1987) and experiments carried out to reconstruct the production process.

Rosch C. et al. (1997) studied some enstatite beads from graves in the oasis of Samad Al Shan (Oman): some unglazed cylindrical beads (dimensions: five millimetres in length, $2.5-3 \mathrm{~mm}$ in diameter) and a short cylindrical bead shaped as a cogged wheel $(6.5 \mathrm{~mm}$ in diameter and $4.5 \mathrm{~mm}$ in height). They used a special sample holder: an almost flat surface segment of the bead was brought onto the focussing circle of diffractometer by a sample mount which was adjustable in height. The $\mathrm{X}$-ray diffraction pattern of the beads revealed an enstatite-related structure. Rosch fired a pure massive steatite at $1000^{\circ} \mathrm{C}$ for 24 hours; he compared the powder diffractogram of the fired bulk steatite with that of the cogged wheel bead and obtained a good overall resemblance. He also fired pulverised talc reshaped into cylinder under the same conditions as the massive steatite. He said that the diffractogram of this fired material was different from diagrams of fired massive bulk steatite; he didn't specify these differences.

Bar-Yosef Mayer et al. (2004) studied white beads, with traces of the glaze, found in a burial cave of Peqi' in, northern Galilee (Israel). The beads range in size from two to four millimetres in diameter, one to three millimetres in height, and hole diameter approximately one millimetre; XRD analyses revealed that the beads are made of enstatite and cristobalite. The authors propose this production process: a paste was prepared from powdered talc, water and perhaps a flux or a binding material; the paste was then shaped into tubes, probably along a thin rod, and fired at a high temperature.
Barthélemy de Saizieu et al. (1994) studied a reconstruction of the production phases used at Mehrgarh, Pakistan; a beads making activity area was found in this site dated in the fifth millennium B.C. The authors proposed that beads were carved directly out of the solid steatite: bars of steatite were obtained by sawing and then were smoothed on four sides, perforated and sliced. Finally, the cylindrical rings thus obtained were fired.

Vidale (1995) tried to reproduce the manufacturing sequence from bulk steatite to steatite beads. The raw material used was steatite stick commonly used in Pakistan for drawing on blackboards. Disks were cut with a copper blade and drilled with a hand drill (the point drill was a chert blade). Finally about 50 beads were strung on a hemp fibre and ground on a grinding stone to remove the corners. After about 25 minutes of grinding, he obtained well rounded beads. The author came to conclusion that the experimental simulations of the manufacturing sequence support the reconstruction proposed.

\section{Conclusion}

Based on X-ray diffraction analysis of the beads and the heating experiments on talc, we propose that the beads from Ra's al-Hadd were produced from steatite; the beads were directly carved out of soft, solid steatite and then hardened by firing at a temperature of at least $1000^{\circ} \mathrm{C}$.

We deduce this because:

- In the diffractograms of the beads the relative intensity of the main peaks is characteristic of syntetic enstatite;

- Peaks of different products deriving from the use of powder steatite, like crystobalite, or peacks relative to products from fluxes, have not been found.

- It is possible that these beads were produced from locally available raw materials.

The raw material of the examined beads, steatite, might have come from the ultramafic rocks of Oman Samail Ophiolite.

Further analysis and heating experiments on steatite from Oman are required to confirm our propositions and to verify the source of the raw material of the beads.

\section{Acknowledgements}

We are grateful to A. Lazzari for the kindly and fundamental collaboration.

\section{References}

BAR-YOSEF MAYER, D.E., PORAT, N., GAL, Z., SHALEM, D., SMITHLINE, H., 2004 - Steatite beads at Peqi'in: long distance trade and pyro-technology during the Chalcolithic of the Levant. Journal of Archaeological Science, 31: 493-502.

\footnotetext{
2 The strongest lines and the relative intensities for protoenstatite are: (File 03-0523) - 4.36(10)-3.16(100)- 2.97(20)-2.90(40)-2.72(20)-2.54(40)2.29(20)-1.96(60).
} 
BARTHELEMY DE SAIZIEU, B., BOUQUILLON, A., 1994 - Steatite working at Mehrgarh during the Neolithic and Chalcolithic periods: quantitative distribution, characterization of material and manufacturing processes. South Asian Archaeology, 1993: 47-59.

CATTANI, M., CURCI, A., MARCUCCI, L.G., TOSI, M., USAI, D., 2001-2002 - Missione Archeologica nel Sultanato di Oman "Joint hadd Project". Campagna di ricerca 2000-2001. OCNUS, 910: $357-366$.

CATTANI, M., TOSI, M., 1997 - Missione Archeologica Italiana nel Sultanato di Oman. OCNUS, 5: 249-254.

FRIFELT, K., 1991 - The Island of Umm An-Nar. Jutland Archaeological Society Publications XXVI, 1: 112-123.
MOSSERI-MARIJIO, C., 1998 - Marine animal resources at Ra's al-Hadd during the Bronze Agc. Bulletin of the Society for Arabian studies: $12-15$.

ROSCH, C., HOCK, R., SCHUSSLER, U., YULE, P., HANNIBAL A., 1997 - Eilectron microprobe analysis and X-ray diffraction methods in archacometry: Investigations on ancient beads from the Sultanate of Oman. European Journal of Mineralogy. 9: 763-783.

VIDALE, M., 1995 - Early beadmakers of the Indus tradition. The Manufacturing scquence of talc beads at Mehrgarh in the $5^{\text {th }}$ Millenium B.C. East and West, 45, 1-4: 45-80.

VIDALE, M., 1987 - Some obscrvations and conjectures on a gToup of stcatite-debitage concentrations on the surface of Mocnjodaro. Annali dell'Istituto Universitario di Napoli, 47/2: 113-129. 